\title{
Genetic diversity in Eddoe Taro (Colocasia esculenta var. antiquorum) from Indonesia based on morphological and nutritional characteristics
}

\author{
DELVI MARETTA ${ }^{1,2, \boldsymbol{v}}$, SOBIR ${ }^{3,4}$, IS HELIANTI ${ }^{5}$, PURWONO $^{4}$, EDI SANTOSA ${ }^{4, \text { v }}$ \\ ${ }^{1}$ Department Agronomy and Horticulture, Faculty of Agriculture, Graduate School, Institut Pertanian Bogor. Jl Meranti, Kampus IPB Darmaga, Bogor \\ 16680, West Java, Indonesia. Tel.: +62-251-8629354, 8629350, ^email: delvi.maretta@ bppt.go.id \\ ${ }^{2}$ Center for Agricultural Production Technology, Deputy of Industrial Technology for Agricultural and Biomedicine, The Agency for Assessment \\ and Application of Technology. Building 614, LAPTIAB-BPPT, PUSPIPTEK, South Tangerang 15314, Banten, Indonesia \\ ${ }^{3}$ Center for Tropical Horticulture Studies, Institut Pertanian Bogor. J1 Raya Pajajaran Kampus IPB Baranangsiang, Bogor 16680 Indonesia \\ ${ }^{4}$ Department Agronomy and Horticulture, Faculty of Agriculture, Institut Pertanian Bogor. Jl Meranti Kampus IPB Darmaga, Bogor 16680 Indonesia. \\ Tel.: +62-251-8629354, 8629350, "vemail: edisang@ gmail.com \\ ${ }^{5}$ Center for Bio-industrial Technology, Deputy of Industrial Technology for Agricultural and Biomedicine, The Agency for Assessment and Application \\ of Technology. Building 614, LAPTIAB-BPPT, PUSPIPTEK, South Tangerang 15314, Banten, Indonesia
}

Manuscript received: 1 May 2020. Revision accepted: 10 July 2020.

\begin{abstract}
Maretta D, Sobir Helianti I, Purwono, Santosa E. 2020. Genetic diversity in Eddoe Taro (Colocasia esculenta var antiquorum) from Indonesia based on morphological and nutritional characteristics. Biodiversitas 21: 3525-3533. Low yield uniformity and quality due to genetic performance become negative incentives to farmers in Eddoe Taro production. However, genetic evaluation is rarely been reported in this taro type in Indonesia. In this study, 14 eddoe genotypes collected from different regions in Indonesia were evaluated to develop a diversity map for crop improvement and future breeding activities. The genotypes were planted in the open field from September 2018 to March 2019 at the experimental station belonging to LAPTIAB-BPPT, PUSPITEK at South Tangerang District, Indonesia. Morphological and nutritional characters were accessed on the shoot and underground parts. The genotypes exhibited variation in 38 out of 48 characters in which 12 quantitative characters were distinct including oxalate level. The study revealed three findings: (i) Characters related to growth and yield had high genotypic variance coefficients, i.e., sheath length, total petiole length, plant height, number of suckers, corm and cormels weight, (ii) Genotypes clustered into two separate groups as introduced and landraces, and (iii) Landraces had high genetic variation leading to speculation of high clonal variation. Considering the findings, accession S6, S7, S18, S30, and S36 are recommended for further studies in crop improvement purposes.
\end{abstract}

Keywords: Crop improvement, Eddoe Taro, genetic properties, glucomannan, oxalate

\section{INTRODUCTION}

Taro (Colocasia esculenta (L.) Schott) is an important food in many localities in the humid tropics and subtropics (Chaï et al. 2016). The corm is rich of nutrients such as carbohydrate, protein, elements (Fe, $\mathrm{Ca}, \mathrm{P}, \mathrm{Mg}, \mathrm{Na}$, and $\mathrm{K}$ ) and vitamins (A, B1, B2, B3, and C) (Ezeabara et al. 2015, Mergedus et al. 2017); the protein level is higher than cassava and sweet potato tubers (Temesgen and Retta 2015). Taro tubers are also important sources of anthocyanins, cyanidin 3-glucoside, and flavonoids that act to improve blood circulation, antioxidants, and inhibit cancer development (Rashmi et al. 2018).

Morphologically, taro has two forms according to the corm and cormel developments, i.e., dasheen and eddoe types that botanically called as Colocasia esculenta var esculenta and Colocasia esculenta var antiquorum, respectively and var esculenta distributes widely in the globe, while var antiquorum predominantly distributes in China and Japan (Plucknett 1983). For this reason, var antiquorum to some extend is called Satoimo or Japanese taro.

In Indonesia, the production of Eddoe Taro is getting popular to fulfill the high demand for export. Since 2013 , about 6,300 tons of frozen taro have been exported to Japan
(ITPC 2014). For such reason, intensive cultivation has been being developed in some districts like Bantaeng (South Sulawesi), Banggai Kepulauan (Central Sulawesi) (Laosa et al. 2016), Kapahiang (Bengkulu) (Amelia and Yumiati 2016) and provinces such as East and West Java (Astuti et al. 2017) and Aceh (Rosdanelly et al. 2018). The Indonesian Government also provides seeds and subsidies to farmers.

However, in the field, many farmers face problems on quality and productivity leading to the low economic benefit of the business. In Eddoe Taro, the quality of cormels is determined by glucomannan and oxalate content. Glucomannan content in taro has been intensively studied (Njintang et al. 2011; Ekowati et al. 2015). The glucomannan is explored in concern to health and beauty (Bateni et al. 2013; Tester and Al-ghazzewi 2016). Glucomannan is a neutral, fermentable and viscous dietary fiber that has been proven to reduce obese (Zalewski et al. 2015), to relieve physiological disorders especially diabetes and cardiovascular diseases (Shah et al. 2015), to reduce blood lipid and cholesterol (Behera and Ray 2016), and to extend storage in the frozen form of processed meat and fish products (Yang et al. 2017). Thus, it is desirable to produce cormels with high glucomannan content. On the other hand, oxalate content as anti-nutrient should be low 
(Akalu and Geleta 2017). The mucilage of the fresh taro causes irritation ( $\mathrm{Yu}$ et al. 2015), stimulates kidney stones, and impairs the absorption of minerals such as iron and calcium in the body (Hang et al. 2013). High oxalate content causes itching in the mouth, burning sensation, and skin irritation (Kaushal et al. 2012; Dewi et al. 2017), leading to low palatability.

One effort to improve quality and yield of the taro is through genetic improvement (Banjaw 2017). Instead of many improved skills on general taro breeding, the diversity of eddoe type in Indonesia is still unknown. Since genotype characterization is a fundamental step onto selection of candidate parents for future breeding programs (Pitoyo et al. 2018). Thus, the study aimed to evaluate morphological and nutritional characters of Eddoe Taro in Indonesia.

\section{MATERIALS AND METHODS}

\section{Study site and plant materials}

The experiment was conducted in rainy season from September 2018 to January 2019 in the open field at Experimental Station of Laboratory for Development of Industrial Technology for Agricultural and Biomedicine (LAPTIAB), Research Center for Science and Technology (PUSPIPTEK) Setu subdistrict, South Tangerang, Banten, Indonesia. The site had altitude $60 \mathrm{~m}$ above sea level (6²1'26.5"S 106³9'56.2"E) with clay soil (Red Yellow Podzolic). The soil had $\mathrm{pH} 6.1$, low $\mathrm{C} / \mathrm{N}$ ratio $(\mathrm{C} / \mathrm{N}=10)$, high available phosphorus (67 mg P2O5/100 g; $\mathrm{HCl} 25 \%$ extraction), low available potassium ( $32 \mathrm{mg} \mathrm{K2O} / 100 \mathrm{~g}$; $\mathrm{HCl} 25 \%$ extraction) and high cation exchangeable capacity $14.58 \mathrm{me} / 100 \mathrm{~g}$ by $\mathrm{NH} 4 \mathrm{CH} 3 \mathrm{CO} 2$ extraction.

Fourteen Eddoe Taro genotypes were obtained from six provinces (Table 1). The type had been verified in the preliminary experiment and coded following the official record. All genotypes are conserved in the LABTIAB facilities with copy genotypes that are maintained at Bogor Agriculture University, Indonesia.

\section{Cultivation method}

All genotypes were planted in two blocks, to minimize the variation of soil fertility. The first block was located at higher soil level, than that of the second block. In each block, the arrangement of the genotype was randomized. Each genotype was planted 5 plants in each block.

Before planting, the soil was plowed and harrowed twice; and the planting site was designed using a raised bed about $15 \mathrm{~cm}$ from the soil level. The width of the planting bed was one meter, and each bed only planted a single line. Soil liming at rate 2 t.ha $^{-1}$ was applied after bedding.

Seed planting used cormlet, seized $2.5-3.5 \mathrm{~cm}$ in diameter, and 30-50 g in weight depending on genotype. Among genotypes, planting distant applied $100 \mathrm{~cm}$, while $60 \mathrm{~cm}$ in a row within a particular genotype. In each planting hole, a single cormlet was used. At planting, the cormlet had no leaf was exist. Organic manure from cow dung was applied at a week before planting, about $1 \mathrm{~kg}$ for each planting hole. NPK fertilizers were applied twice. The first application was conducted four weeks after planting (WAP) using one-third of the total NPK dose. The second application using the rest of the dose was conducted at 12 WAP. NPK fertilizer derived from single fertilizer, i.e., 120 kg.ha- ${ }^{-1}$ Urea $(46 \% \mathrm{~N}), 50 \mathrm{~kg} \cdot \mathrm{ha}^{1} \mathrm{SP} 36\left(36 \% \mathrm{P}_{2} \mathrm{O}_{5}\right)$ and 150 kg.ha ${ }^{-1} \mathrm{KCl}\left(60 \% \quad \mathrm{~K}_{2} \mathrm{O}\right) /$. Weeding used manual and pesticide spraying using common chemicals according to field conditions.

\section{Morphological evaluation}

Morphological data were obtained at maximum vegetative growth (14 WAP) and at harvesting time (20 WAP). Morphological description followed IPGRI (1999), and nutritional characters focused on chlorophyll, oxalate, and glucomannan contents. Thus, a total of 48 characters were evaluated.

The morphological evaluation focused on plant habit, leaf, petiole, corm, cormel, and root (Figure 1). Plant habits included plant height $(\mathrm{Ph})$, plant span (Ps), and the number of suckers. Leaf characters included leaf base, predominant position of leaf lamina surface, leaf blade margin, leaf blade color, leaf blade margin color, leaf lamina appendages, leaf main vein color, vein pattern, lamina length, lamina width, sheath length, leaf sheath edge color, and leaf waxiness. Petiole characters included petiole junction pattern, petiole junction color, petiole stripe, petiole stripe color, petiole basal-ring color, the crosssection of the lower part of petiole, and total petiole length. Corm characters included corm manifestation, length, corm branching, shape, weight, cortex color, flesh color of the central part, corm flesh fiber color, skin surface, skin thickness, degree of fibrousness of corm, and bud color. Cormel characters included weight, number, shape, flesh color of cormels, and root characters included color and uniformity of color.

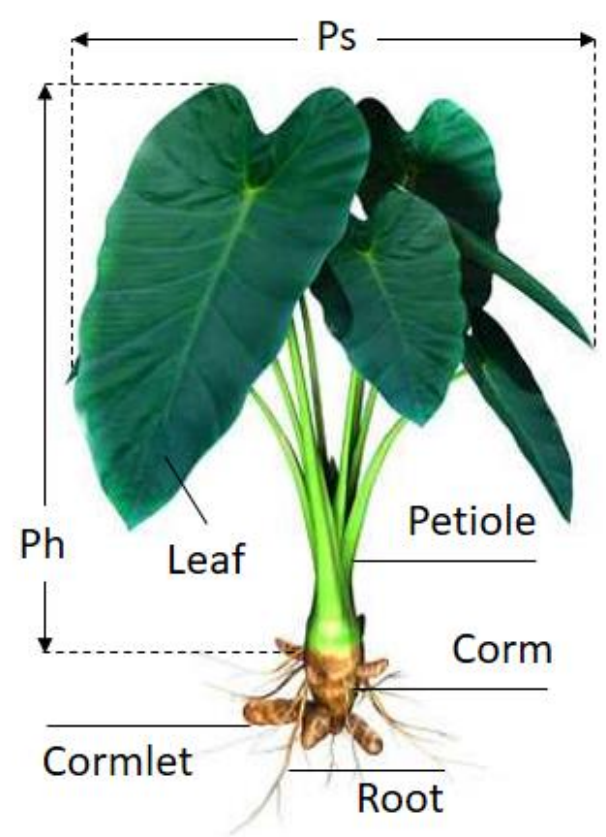

Figure 1. Part of the eddo taro plant. Note: Ph-plant height, PsPlant span (Picture adopted from https://www.seedsofindia.com) 


\section{Nutritional analysis}

Glucomannan and oxalate were analyzed from mixed flour of corm and cormlets. The preparation followed to Chairul and Chairul (2006). After cleaning, corm/cormlets were peeled, thin-sliced and oven-dried at $80^{\circ} \mathrm{C}$ for 20 hours continuously. The dried-chips then were made into flour using a blender (Madato type) and then shieved using 80 mesh before preparing the analysis.

Glucomannan analysis used the gravimetric method of Widjanarko and Megawati (2015). Five-gram taro flour was added to preheated $50 \mathrm{~mL}$ distilled water $\left(75^{\circ} \mathrm{C}\right)$ plus $0.5 \mathrm{~g} \mathrm{Al}_{2}\left(\mathrm{SO}_{4}\right)_{3}$ (10\% of sample weight) in Erlenmeyer glass inside the water bath. The mixture was kept at $75^{\circ} \mathrm{C}$ while stirring for $35 \mathrm{~min}$, then the solution was transferred into falcon tube $50 \mathrm{~mL}$ and centrifuged at $2000 \mathrm{rpm}\left(25^{\circ} \mathrm{C}\right.$ for $30 \mathrm{~min}$ ). The supernatant was transferred to a new falcon tube and then added isopropyl alcohol 1:1 (v/v). The supernatant was inverted until coagulated. The pellet was then filtered using filter paper (Whatman No 1 qualitative $\varnothing 125 \mathrm{~mm}$ ) equipped with a vacuum pump (Rocker 300 type). Finally, the pellet was oven-dried at $60^{\circ} \mathrm{C}$ for 24 hours. Percentage glucomannan content on dry basis was estimated from ratio final weight to sample weight.

Oxalate analysis referred to Naik et al. (2014). Initially, taro flour weighed $0.25 \mathrm{~g}$ was transferred in to test tube, added $10 \mathrm{~mL} 0.25 \mathrm{~N} \mathrm{HCl}$, and then heated at $85-90^{\circ} \mathrm{C}$ for $15 \mathrm{~min}$ in the water bath. After cooling in room temperature, the volume was adjusted into $25 \mathrm{~mL}$ with $0.25 \mathrm{~N}$ $\mathrm{HCl}$ and mixed gently. The supernatant $(1 \mathrm{~mL})$ was then used for oxalic acid measurement using spectrophotometric.

Before measurement, the fresh stock solution was prepared. For this purpose, $1000 \mathrm{ppm}$ standard solution was developed from $139.6063 \mathrm{~g}$ oxalic acid $\left(\mathrm{C}_{2} \mathrm{H}_{2} \mathrm{O}_{4} \cdot 2 \mathrm{H}_{2} \mathrm{O}\right)$ diluted in 100 distilled water. The second stock was $0.02 \mathrm{M}$ $\mathrm{KMnO}_{4}$, it was prepared by dissolving $3.1606 \mathrm{~g} \mathrm{KMnO}_{4}$ into $1 \mathrm{~L}$ distilled water. The third stock was $2 \mathrm{~N} \mathrm{H}_{2} \mathrm{SO}_{4}$, it was made by dissolving $27.8 \mathrm{~mL}$ concentrate $\mathrm{H}_{2} \mathrm{SO}_{4}$ with distilled water into a final volume of $500 \mathrm{~mL}$. The standard solution was made for $0,5,10,15,20,25,30,35,40,45$ and $50 \mathrm{ppm}$ of the oxalic acid standard solution. In each 1
$\mathrm{mL}$ solution was added $5 \mathrm{~mL} 2 \mathrm{~N} \mathrm{H}_{2} \mathrm{SO}_{4}$ and $2 \mathrm{~mL}$ of $0.003 \mathrm{M} \mathrm{KMnO}_{4}$, then incubated at room temperature $\left(27 \pm 2^{\circ} \mathrm{C}\right)$ for at least $10 \mathrm{~min}$. The measurement used UV1800 spectrophotometric Shimadzu at $528 \mathrm{~nm}$.

\section{Data analysis}

Analysis of variance (ANOVA) was performed by Ftest to investigate the presence of statistically significant differences among genotypes for quantitative characters. Duncan's multiple range test $p<0.05$ was addressed to estimate genotypic differences by optimizing the block as replication.

Cladogram analysis used DARwin 6 (http://darwin.cirad.fr) by utilizing all quantitative and qualitative data. In the clustering process, the software was set in dissimilarity mode, unweighed neighbor-joining and bootstrap 1000 times.

The relationships among genotypes was estimated using STRUCTURE 2.3.4, using combining data of quantitative and qualitative characters. The calculation used the admixture model, length of period 100,000 , number of MCMC repeat after burned $100,000, \mathrm{~K}=3$, and the number of iteration 20. Optimum $\mathrm{K}$ was determined by using Structure Harvester (Earl et al. 2012) through online (http://taylor0.biology.ucla.edu/structureHarvester).

Genotypic and phenotypic variances estimation and the calculation of the variance coefficient followed Syukur et al. (2015). The formulas as follows: Genotypic variance $\left(\sigma^{2} \mathrm{~g}\right)=$ MSg-MSe; Genotypic variance coefficient (GVC): $\left[\sqrt{ } \sigma^{2} \mathrm{~g} / \mathrm{x}\right] \times \mathrm{x}$ 100; Phenotypic variance $\left(\sigma^{2} \mathrm{p}\right)=\sigma^{2} \mathrm{~g}+\mathrm{MSe}$; Phenotypic variance coefficient $\left.(\mathrm{PVC}):\left[\sqrt{ } \sigma^{2} \mathrm{p}\right) / \mathrm{x}\right]$ x 100 ; Here, MSg and MSe denoted genotypic and error means square, respectively. The ' $r$ ' represented replication $(n=2)$ and ' $x$ ' represented mean value. Deshmukh et al. (1986) classified PVC and GVC as high (> 20\%), medium (10 to $20 \%)$, and low $(<10 \%)$. Estimate of broad-sense heritability $\left(\mathrm{h}^{2}\right)$ was calculated based on variant value of genetic and phenotypic follow Stansfield (1983), $\mathrm{h}^{2}=\frac{\sigma^{2} \xi}{\sigma^{2} \mathrm{r}}$; the $h^{2}$ was classified as high $\left(h^{2}>0.50\right)$, medium $\left(0.20 \leq h^{2}\right.$ $\leq 0.50)$, and low $\left(\mathrm{h}^{2}<0.20\right)$.

Table 1. Site of origin of 14 Eddoe Taro accessions

\begin{tabular}{|c|c|c|c|c|c|}
\hline Code & Local name & Collecting site (Subdistrict, District, Province) & Habitat* & $\begin{array}{c}\text { (Altitude m } \\
\text { asl) }\end{array}$ & Origin \\
\hline S6 & Safira & Bontadaeng, Bantaeng, South Sulawesi & $\mathrm{AF}$ & 750 & LR \\
\hline S7 & Satoimo & Bontadaeng, Bantaeng, South Sulawesi & $\mathrm{AF}$ & 750 & IN \\
\hline S15 & Satoimo & Lembah Seulawah, Aceh Besar, Aceh & $\mathrm{AF}$ & 150 & IN \\
\hline S17 & Dempel & Trowulan, Mojokerto, East Java & HG & 30 & LR \\
\hline S18 & Talas Oshikawa & Kepung, Kediri, East Java & $\mathrm{AF}$ & 60 & IN \\
\hline S20 & Bentul & Batu, Malang, East Java & RG & 445 & LR \\
\hline S24 & Talas Oshikawa & Lamongan, Lamongan, East Java & $\mathrm{AF}$ & 6 & IN \\
\hline S26 & Salak & Karang Asem, Karang Asem, Bali & HG & 88 & LR \\
\hline S28 & Bentul & Pesantren, Kediri, East Java & HG & 60 & LR \\
\hline S30 & Keladi & Belitang, Belitang, South Sumatra & $\mathrm{AF}$ & 40 & LR \\
\hline S33 & Brentel & Sooko, Mojokerto, East Java & HG & 30 & LR \\
\hline S34 & Japanese taro & Lilirilau, Soppeng, South Sulawesi & $\mathrm{AF}$ & 90 & IN \\
\hline S35 & Japanese taro & Batulappa, Pinrang, South Sulawesi & $\mathrm{AF}$ & 50 & IN \\
\hline S36 & Ngariung Indung & Santana, Kuningan, West Java & $\mathrm{AF}$ & 760 & LR \\
\hline
\end{tabular}

Note: * AF-agriculture farmer field, HG-homegarden, RG-grow wild in the experimental field garden; ** LR-landrace, IN-Recently introduced according to farmer information, but dating unknown 


\section{RESULTS AND DISCUSSION}

\section{Morphological and nutritional characters}

Eddoe genotypes collected from Indonesia showed variation in leaf, petiole, corm, and cormels (Figure 2). Among 48 characters used in the genotyping, 38 characters showed variation including qualitative and quantitative characters. Twelve out of 15 quantitative characters exhibited significant variation among genotypes (Table 2). There was no significant difference for corm diameter, number of cormlet and glucomannan content. Table 2 shows characters related to plant growth and production like chlorophyll content, leaf size, plant size, number of the sucker, corm size, and cormlet weight had variation among genotypes.

Moreover, oxalate content in the corm and cormlets significantly varied among genotypes (Table 2). Low oxalate level is an important indicator for taro palatability affected by genotype (Nurilmala and Mardiana 2019); the level of the oxalate content could be reduced by cooking (Hang et al. 2013). We confirmed here that genotype had a different level of oxalate. This fact could be an important consideration in crop improvement to address farmer's problems in cormel quality.

From 33 qualitative characters observed, 28 characters showed variation among genotypes. The variation was found in leaf blade margin, leaf lamina appendages, leaf blade margin color, leaf sheath color, and vein pattern. Here, seven characters were presented; these characters could be easily distinguished for genotyping including by farmers (Table 3). Among leaf morphological characters, sheath color and vein patterns were easily recognized. Three accessions had red-purple sheath, i.e., S26, S28, and S33 genotypes, while the others were light green. The common vein pattern was V-pattern, followed by Y-pattern extending to secondary vein and Y-pattern. Y-pattern was found in single accession S20 from Malang District (Table $1)$.

Petiole varied in whole color, junction, stripe, and basal-ring color. Here, the whole petiole color was the most prominent character compared to other petiole characters. The whole petiole mostly was light green, but brown existed for S26 and S30, and purple was found in S28 and S33 genotypes (Table 3). Rudyatmi and Rahayu (2014) reported that taro with purple petiole was known as black taro.

Corm exhibited variation in shape, cortex color, flesh color of the central part, flesh fiber color, skin thickness, fibrousness degree of corm and bud color; with corm shape and bud color were the most discernible characters. S28 was the only genotype with cylindrical corms (Table 3). Corm with dumb-bell shape existed in two genotypes, conical shape in four and round shape in seven genotypes. Corm dumb-bell and round shape was also found in $C$. esculenta characterized by Sinaga et al. (2017). Bud color was yellow-green in S20, S28 and S33 genotypes, and pink-red in the other 11 accessions. Table 3 shows that all genotypes with round corm had pink-red corm bud. Corm commonly had a big size and located at the central such as in S6, S20, and S36 genotypes. However, for some genotypes like S18, S34 and S35 had the corm size almost the same size as its cormlets (Figure 2C).

Table 2. ANOVA for quantitative characters of 14 Eddoe Taro genotypes from Indonesia

\begin{tabular}{|c|c|c|c|c|c|c|c|}
\hline Characters & Mean \pm SD & SS & MS & F Value & R-Square & $\mathbf{C V}$ & Sig \\
\hline \multicolumn{8}{|l|}{ Leaf lamina } \\
\hline Length $(\mathrm{cm})$ & $36.1 \pm 8.6$ & 1607.76 & 123.67 & 5.81 & 0.86 & 12.79 & $* *$ \\
\hline Width $(\mathrm{cm})$ & $12.7 \pm 2.8$ & 158.99 & 12.23 & 4.89 & 0.84 & 12.49 & $* *$ \\
\hline Sheath length $(\mathrm{cm})$ & $22.1 \pm 5.5$ & 688.66 & 52.97 & 6.81 & 0.88 & 12.64 & $* *$ \\
\hline Total petiole length $(\mathrm{cm})$ & $62.1 \pm 23.1$ & 12285.81 & 945.06 & 8.24 & 0.90 & 17.24 & $* *$ \\
\hline Plant width $(\mathrm{cm})$ & $93.7 \pm 23.7$ & 10208.65 & 785.28 & 3.25 & 0.79 & 16.58 & $*$ \\
\hline Plant height (cm) & $81.8 \pm 27.8$ & 17775.32 & 1367.33 & 8.28 & 0.90 & 15.71 & $* *$ \\
\hline Number of sucker & $5.7 \pm 3.4$ & 214.69 & 16.51 & 3.34 & 0.79 & 39.27 & $*$ \\
\hline \multicolumn{8}{|l|}{ Corm } \\
\hline Length (cm) & $61.0 \pm 13.5$ & 4232.96 & 325.61 & 7.08 & 0.88 & 11.12 & $* *$ \\
\hline Diameter $(\mathrm{cm})$ & $56.5 \pm 7.2$ & 885.72 & 68.13 & 1.87 & 0.66 & 10.69 & ns \\
\hline Weight (g) & $95.5 \pm 36.9$ & 1375410.69 & 105800.82 & 5.97 & 0.81 & 24.04 & $* *$ \\
\hline \multicolumn{8}{|l|}{ Cormlet } \\
\hline Number & $24.3 \pm 10.1$ & 1705.90 & 131.22 & 1.91 & 0.67 & 34.17 & ns \\
\hline Weight (g) & $425.8 \pm 47.3$ & 1375410.69 & 105800.82 & 5.97 & 0.87 & 31.27 & $* *$ \\
\hline Chlorophyll (mg/g) & $57.6 \pm 5.2$ & 520.89 & 40.07 & 2.58 & 0.72 & 6.84 & $*$ \\
\hline Oxalate (ppm) & $94.8 \pm 32.8$ & 15738.99 & 1210.69 & 3.47 & 0.85 & 19.69 & $*$ \\
\hline Glucomannan (\%) & $5.7 \pm 1.5$ & 39.40 & 3.03 & 2.23 & 0.69 & 20.43 & ns \\
\hline
\end{tabular}



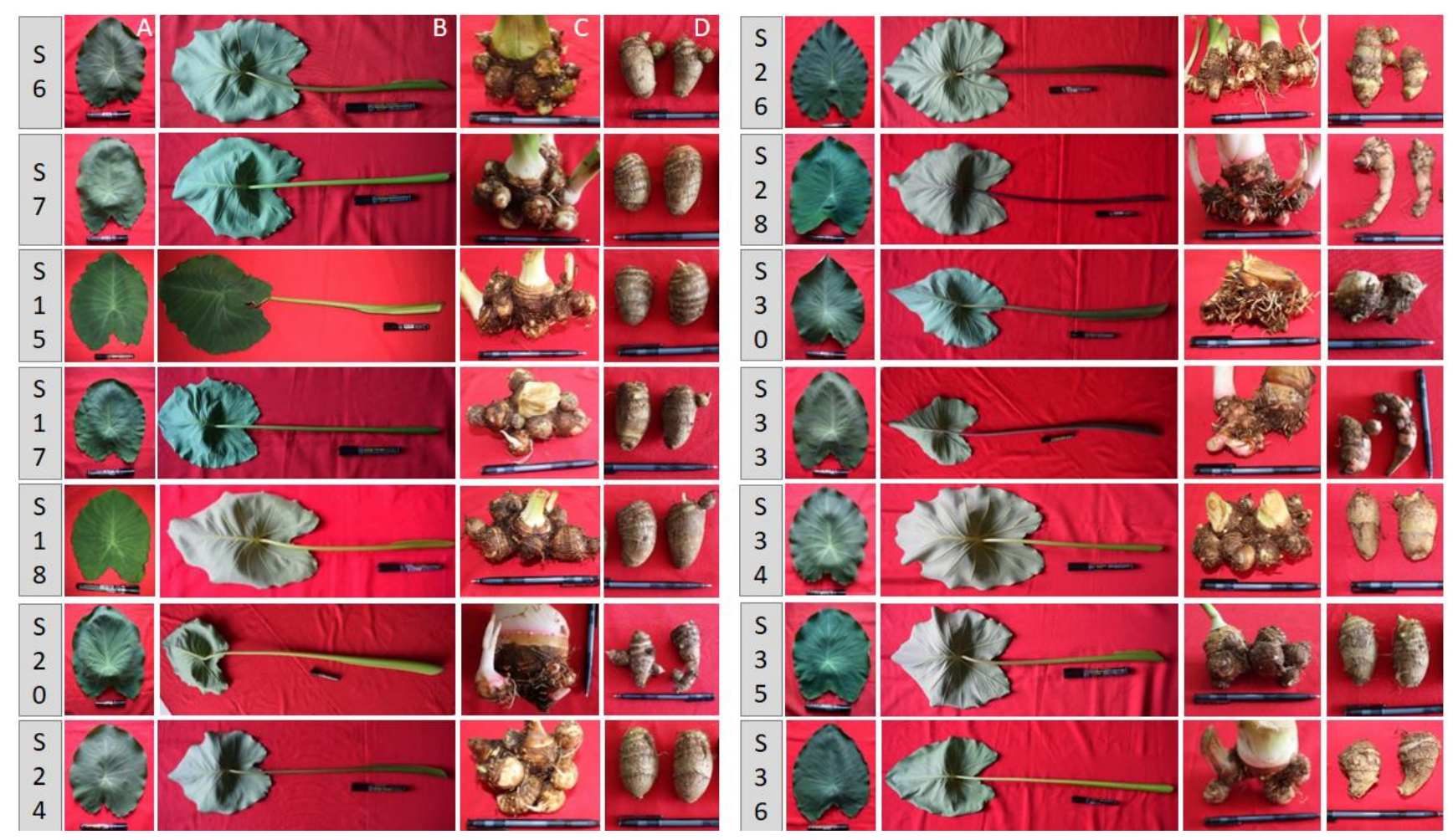

Figure 2. The appearance of leaf lamina (A), petiol (B), corm (C), and cormlets (D) of 14 Eddoe Taro genotypes from Indonesia

Table 3. Selected morphological data of 14 Eddoe Taro genotypes from Indonesia

\begin{tabular}{|c|c|c|c|c|c|c|c|c|c|c|c|c|c|c|}
\hline \multirow{2}{*}{ Characters } & \multicolumn{14}{|c|}{ Genotype code } \\
\hline & S6 & S7 & S15 & S17 & S 18 & S20 & S24 & S 26 & S28 & S30 & S 33 & S34 & S35 & S 36 \\
\hline Sheath color & 1 & 1 & 1 & 1 & 1 & 1 & 1 & 2 & 2 & 1 & 2 & 1 & 1 & 1 \\
\hline Vein pattern at leaf base & 3 & 3 & 3 & 3 & 3 & 1 & 3 & 2 & 2 & 2 & 2 & 3 & 3 & 3 \\
\hline Whole petiole color & 3 & 3 & 3 & 3 & 3 & 3 & 3 & 1 & 2 & 1 & 2 & 3 & 3 & 3 \\
\hline Corm shape & 4 & 4 & 4 & 4 & 4 & 3 & 4 & 3 & 1 & 3 & 3 & 2 & 4 & 2 \\
\hline Bud color & 2 & 2 & 2 & 2 & 2 & 1 & 2 & 2 & 1 & 2 & 1 & 2 & 2 & 2 \\
\hline Cormlet shape & 4 & 4 & 4 & 4 & 4 & 3 & 4 & 2 & 3 & 1 & 3 & 4 & 4 & 4 \\
\hline Root color & 2 & 2 & 2 & 2 & 2 & 1 & 2 & 2 & 1 & 2 & 1 & 2 & 2 & 2 \\
\hline
\end{tabular}

Note: Sheath color (1-light green, 2-red purplish), Vein pattern at leaf base (1-Y pattern, 2- Y-pattern extending to the secondary vein, 3V pattern), Whole petiole color (1-brown, 2-purple, 3-light green), Corm shape (1-cylindrical, 2-dumb-bell, 3-conical, 4-round), Bud color (1-yellow green, 2-pink-red), Cormlet shape (1-conical, 2-elongated, 3-elongated-curved, 4-elliptical), Root color (1-pinkish white, 2-white)

\section{Genetic properties}

GVC and PVC for important quantitative characters significantly varied from low to high (Table 4). Six characters had high criteria GVC, i.e, sheath length, total petiole length, plant height, number of sucker, corm and cormlets weight. Chlorophyll content contributed to low GVC, and it was the lowest among characters. On the other side, all PVC was high, except for the character of chlorophyll content. In the present study, all PVC values were higher than the GVC. This finding is a common case in the genotypic evaluation such as in other crops (Effendy et al. 2018).

In the breeding process, genotype selection based on characters with high heritability and high genetic variation is desirable. Heritability value would determine the selection method of plant characters because it gives a portion of genetic and phenotypic variation that is inherited (Sleper and Poehlman 2006). According to Jalata et al. (2011), broad genetic diversity would speed the success of the selection and breeding progress. Effendy et al. (2018) pointed out that high genetic variation of particular characters within a population reflected the span of genetic control and the high genetic control means expected product of the breeding process could be estimated more precisely. In the present experiment, the estimate of broadsense heritability and PVC of all characters showed high, except the chlorophyll content that showed medium and low. High GVC found in characters sheath length, total petiole length, plant height, number of suckers, weight of corm, cormlets weight and oxalate content (Table 4). The high genetic diversity would enlarge chances of success selection in plant breeding due to the higher frequency of 
genes (Hapsari 2014). Confirmable to Eze and Nwofia (2016) that plant height, number of suckers, length, and weight of corm and cormlet weight has high heritability. This research result reveals additional information that oxalate content also has a high value of heritability, PVC and GVC. It indicates that the quantitative characters as listed in Table 4 could be used in the selection program.

On the contrary, Mulualem and Michael (2013) reported that the quantitative characters of Colocasia esculenta had low or medium PVC, GVC, and heritability. Low heritability value indicated a character inherited complicatedly and influenced by environment factors (Meydina et al. 2015). Refers to Sleper and Poehlman (2006) the effectiveness of selection depends on the variability of the individual in the population and the variability among plants due to the environment. For that reason, the selection of these all Eddoe Taro genotypes highly recommended to be examined in multi-location or different season conditions to find out which genotypes perform consistently in a wide range of environments.

\section{Genotype grouping}

Genotypes separated into two groups with sevenmember in each group, Group-1 (S18, S20, S26, S28, S30, S33, and S36) and Group-2 (S6, S7, S15, S17, S24, S34, and S35) (Figure 3). Group-2 represented the 'satoimo group' judge from the local name, except Safira (S6) and Dempel (S17). Cladogram showed S6 separated to other members including S7. Unexpectedly, S6 and S7 genotypes that geographically close (Table 1), were separated distantly in the cluster Group-2.

According to farmers that cultivated the S7 accession, they received the seed from the local government of South Sulawesi province. The local government imported seeds from Japan through a trading company. The seeds were propagated by the trading company and then distributed to some Districts within South Sulawesi, including other provinces such as Aceh and East Java, so farmers maintained the accessions name as 'satoimo' of Japanese. Therefore, it is presumable that Satoimo group shared similar ancestor based on morphological characters; and the ancestor was likely derived from S7 in Bantaeng District, South Sulawesi. In Aceh, Eddoe Taro was reintroduced around 2014 almost the same time reintroduction to Buleleng District in Bali (Taufiq 2015); thus it supported that Aceh accession S15 clustered in Satoimo group.

High genetic variation within satoimo group as shown in Figure 3, indicated that clonal variation could be high in eddoe type. There probably was genetic distant between S6 and S7 although geographically close due to clonal variation. On the other side, Group-1 represented the local landrace. It is still unclear, S18 that had a similar name with S24 'Talas Oshikawa' clustered to a different group. In general, morphological variation within Group-1 was larger than the variation within Group-2 (Figure 3). It needs further evaluation using molecular markers the reliability in this grouping.

Genotype grouping using a cladogram was consistent with grouping based on population assessment using STRUCTURE (Figure 4). The population grouped into two types, Type-1 and Type-2. The Type-1 was indicated by light grey color consisted of eight genotypes (S6, S7, S15, S17, S18, S24, S34, S35, S36) and shows high uniformity. The type-1 population included all accessions in the Group2 cladogram (Figure 3), and the clustering was exactly matched with a local name especially S18 that unable to be resolved using the cladogram. Here, almost all accessions under Type-1 were taken from the commercial field at which based on farmer interview the parent seeds were imported except for S6, S17, and S36 that obtained from local farmers. Considering these genotypes shared the same ancestor, this finding envisages the hypothesis that clonal variation could be high in Eddoe Taro.

Type-2 had five members, i.e., S20, S26, S28, S30, and S33 indicated by a mixture of black and dark grey colors (Figure 4). Type-2 accessions corresponding to Group-1 in the cladogram. This type, most probably as original landraces in Indonesia.

Table 4. Genotypic and phenotypic variances and it's coefficient for 12 quantitative characters of Eddoe Taro in Indonesia

\begin{tabular}{|c|c|c|c|c|c|c|c|c|}
\hline \multirow{2}{*}{$\begin{array}{l}\text { Character } \\
\text { Leaf lamina }\end{array}$} & \multirow[t]{2}{*}{$\sigma^{2} g$} & \multirow[t]{2}{*}{$\sigma^{2} \mathbf{p}$} & \multicolumn{2}{|c|}{$\mathbf{h}^{2}$} & \multicolumn{2}{|c|}{ GVC $(\%)$} & \multicolumn{2}{|c|}{$\operatorname{PVC}(\%)$} \\
\hline & & & & & & & & \\
\hline Length & 51.20 & 72.48 & 0.71 & $* * *$ & 19.84 & $* *$ & 23.60 & $* * *$ \\
\hline Width & 4.86 & 7.37 & 0.66 & $* * *$ & 17.42 & ** & 21.44 & $* * *$ \\
\hline Sheath length & 22.59 & 30.38 & 0.74 & $* * *$ & 21.54 & $* * *$ & 24.97 & $* * *$ \\
\hline Total petiole length & 415.18 & 529.88 & 0.78 & $* * *$ & 32.80 & $* * *$ & 37.06 & $* * *$ \\
\hline \multicolumn{9}{|l|}{ Plant size } \\
\hline Plant span & 271.96 & 513.32 & 0.53 & $* * *$ & 17.60 & $* *$ & 24.18 & $* * *$ \\
\hline Plant height & 601.09 & 766.24 & 0.78 & $* * *$ & 29.96 & $* * *$ & 33.83 & $* * *$ \\
\hline Number of suckers & 5.79 & 10.73 & 0.54 & $* * *$ & 42.50 & $* * *$ & 57.87 & $* * *$ \\
\hline \multicolumn{9}{|l|}{ Corm } \\
\hline Length & 139.82 & 185.80 & 0.75 & $* * *$ & 19.40 & $* *$ & 22.36 & $* * *$ \\
\hline Weight & 878.63 & $1,406.01$ & 0.62 & $* * *$ & 31.03 & $* * *$ & 39.25 & $* * *$ \\
\hline Cormlets weight & $44,036.55$ & $61,764.27$ & 0.71 & $* * *$ & 49.28 & $* * *$ & 58.36 & $* * *$ \\
\hline Chlorophyll content & 12.26 & 27.80 & 0.44 & $* *$ & 6.08 & $*$ & 9.15 & $*$ \\
\hline Oxalate content & 431.12 & 779.57 & 0.55 & $* * *$ & 21.90 & $* *$ & 29.45 & $* * *$ \\
\hline
\end{tabular}

Note: GVC-Genotypic variance coefficient; PVC-phenotypic variance coefficient; ***high, **medium, *low 


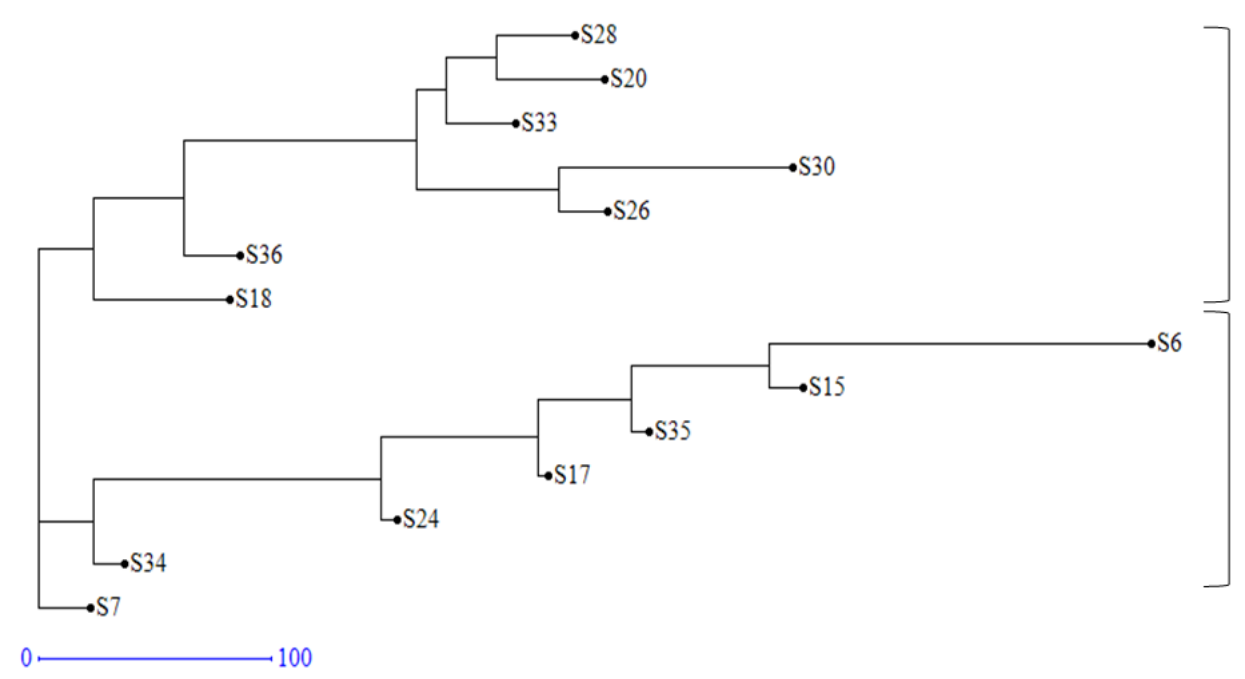

Figure 3. Cladogram of 14 Eddoe Taro genotypes collected from Indonesia. Bar indicates dissimilarity distant. The genotype name is presented in Table 1

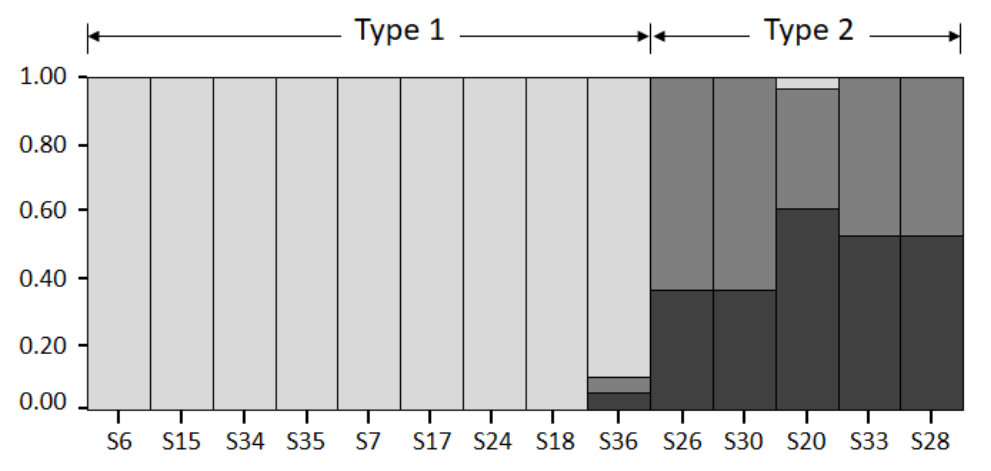

Figure 4. The genetic population structure of Eddoe Taro in Indonesia is drawn by STRUCTURE

Figure 4 shows that genetically, S36 seemed as an intermediary type between Type- 1 and Type- 2 clusters. Since S36 contained many share characters from population Type-1 lead to join the Type-1 in the present analysis. Considering that Type- 1 just recently introduced, it is difficult to conclude that S36 was a result of breeding Type- 1 and Type- 2 genotypes. Moreover, based on genetic composition it is likely that Type- 2 genotypes were clonal variant from S36 in Kuningan District.

\section{Source of genetic variation}

We speculated that morphological and nutritional variation in Eddoe Taro from Indonesia arose from a combination of multiple introduction and clonal variation. The first introduction could be around the 1940s or before. This assumption based on information from Prana (2007) where the eddoe type is only found at an isolated site like 'Talas bithek' in Tana Toraja District and 'Talas salak' in Buleleng District, Bali, in which these sites had intense interaction with Japanese in the past time. Fortunately, we incorporated 'Talas salak' from Karangasem District, Bali (code S26) that geographically less than $100 \mathrm{~km}$; it was involved in Group-1 and Type-2. Here, Group-1 or Type-2 was represented as the first introduction. According to information from senior farmers (> 80-year old) in Sooko village, Mojokerto, he claimed that the seeds of 'Brentel' (S33) were introduced by the Japanese army in around 1940s to support their logistic in East Java. His information was confirmed in the cladogram dan dendrogram (Figures 3 and 4). It is confident to note that S20, S26, S28, S30, and S33 arisen from the first introduction.

The second introduction was represented by genotypes belongs to Group-2 cladogram or Type-1 dendrogram such as S6, S7, S15, S17, S24, S34 and S35 (Figures 3 and 4). The introduction could be around the 2000s through South Sulawesi after the establishment of the 'Satoimo Consortium Project in 2004' involving Japanese and Indonesian companies (Kallo et al. 2019). According to Das et al. (2015), Eddoe Taro has diversity in chromosome numbers. Thus, it is probable that the Japanese introduced different cultivars for the first and second periods.

Presence of genetic variation within-cluster group in Figure 3 probably due to clonal variation after generations. According to Vandenbroucke et al. (2016), clonal variation in taro was about 3\%. After the first phase of the introduction, the development of Eddoe Taro could be 
restricted by unknown reasons. The success of the Green Revolution in Indonesia leading to the high availability of rice (Poerwanto et al. 2012, Yunus et al. 2016), could be one explanation Eddoe Taro became less utilized. During the survey, many farmers in East Java stated that Eddoe Taro was abandoned ones, even sometimes called a weed. The eddoe underwent dormant during the dry season; the dormancy might limit continuous availability, unlike dasheen type that available throughout the year. The case nearly similar to clonally propagated Amorphophallus paeoniifolius as a neglected crop in Java after the green revolution (Santosa et al. 2017).

As a result, eddoe genotypes such as S36 were cultivated in a limited area at highland in Kuningan District, West Java along the edge of a vegetable field close to Ceremai Mt. Locally, S36 called Ngariung indung or lahun indung means 'mother carrying the son'. Sometimes the boiling cormlets were available in the local market. According to Kuningan people, particular cormlets have been known available in the market since the 1970s.

S36 was an exceptional genotype. According to the clade diagram, it is grouped with genotypes into the first phase of introduction (Figure 3) but genetic composition indicated a high proportion of the second phase of introduction (Figure 4). Judgment from the timeline, the S36 was most likely as descendent from the first phase of introduction but underwent genetic manipulation. The genetic manipulation is less likely from natural mating because flowering on eddoe type in the field was a rare case. According to Susepah (2018), Sundanese in Kuningan is a famous retailer that travels across Indonesian cities. The Kuningan genotype probably originated from clonal variation, like in clonally propagated $A$. paeoniifolius (Santosa et al. 2010). Nevertheless, the hypothesis needs further evaluation because in the present experiment the original variety of satoimo from Japan was not incorporated.

To develop better cormlets quality and production, it is important to consider this genetic diversity and historical data. After years, first introduced-genotype probably has adapted with Indonesian agro climate, while second introduced-genotype has superiority in the palatability and global acceptance. Therefore, it is recommended to use genotype S6, S7, S18, S30 and S36 for further breeding purposes. In conclusion, genetic diversity based on morphological characters was considered high in eddo taro in Indonesia as representing by major characters such as sheath and petiole color, vein pattern at the leaf base, leaf size, plant size, cormels size and oxalate content. On the other hand, the cormlets number and glucomannan content were statistically similar. The cause of such high diversity is presumably caused by multiple introductions from Japan and variation in clonal propagation. However, it needs further clarification using a robust genotyping method such as a molecular marker. Based on distinct grouping, five genotypes, i.e., S6, S7, S18, S30, and S36 could be considered as parents in the future breeding program and a multi-location examination is recommended to determine the consistency perform of genotypes.

\section{ACKNOWLEDGEMENTS}

The authors' thanks to The Ministry of Research and Technology, the Republic of Indonesia for financial support through Saintek Scholarship and The Agency of Application and Assessment of Technology Indonesia (BPPT) for providing research facilities.

\section{REFERENCES}

Akalu ZK, Geleta SH. 2017. Antinutritional levels of tubers of Colocasia esculenta L. Schott (Taro) and Dioscorea alata (Yam) cultivated in Ethiopia. J Nutr Food Sci 7: 2. DOI: 10.4172/2155-9600.1000585.

Amelia DD, Yumiati Y. 2016. Analysis of satoimo taro farming (Colocasia esculenta var. antiqourum) (Case study in Sukasari Village, Kabawetan subdistrict, Kepahiang District. J Agritepa 2 (2): 188-198. [Indonesian]

Astuti SD, Andarwulan N, Fardiaz D, Purnomo EH. 2017. The characterization of satoimo taro flour produced by controlled fermentation using L. plantarum and S. cerevisiae. Proc. Semin. Nas. Pangan, Gizi Kesehatan 796-809. [Indonesian]

Banjaw DT. 2017. Review of taro (Colocasia esculenta) genetics and breeding. J Hortic 4: 1. DOI: 10.4172/2376-0354.1000196

Bateni E, Tester R, Al-Ghazzewi F, Bateni S, Alvani K, Piggott J. 2013. The use of konjac glucomannan hydrolysates $(\mathrm{GMH})$ to improve the health of the skin and reduce acne vulgaris. Am J Dermatol Venereol. 2 (2): 10-14. DOI: 10.5923/j.ajdv.20130202.02.

Behera SS, Ray RC. 2016. Konjac glucomannan, a promising polysaccharide of Amorphophallus konjac K. Koch in health care. Int J Biol Macromol 92: 942-956. DOI: 10.1016/j.ijbiomac.2016.07.098

Chairul C, Chairul S. 2006. Isolation of glucomannan from two species of Araceae: Taro (Colocasia esculenta (L .) Schott) and elephant foot yam (Amorphophallus campanulatus Blumei). Berita Biol 8 (3): 171178. [Indonesian]

Chaïr H, Traore RE, Duval MF, Rivallan R, Mukherjee A, Aboagye LM, Rensburg WJ, Andrianavalona V, Carvalho P, Saborio F, Prana MS, Komolong B, Lawac F, Lebot V. 2016. Genetic diversification and dispersal of taro (Colocasia esculenta (L.) Schott). PLoS ONE. DOI: 10.1371/journal.pone.0157712

Das AB, Das A, Pradhan C, Naskar SK. 2015. Genotypic variations of ten Indian cultivars of Colocasia esculenta var. antiquorum Schott. evident by chromosomal and RAPD markers. Caryologia 68(1): 4454. DOI: $10.1080 / 00087114.2015 .1013335$

Deshmukh SN, Basu MS, Reddy PS. 1986. Genetic variability, character association and path coefficient analysis of quantitative traits in Virginia bunch varieties of groundnut. Indian J Agro Sci 56: 515-518.

Dewi SK, Dwiloka B, Setiani BE. 2017. Reduction of oxalate levels in taro tubers by adding activated charcoal to the steaming method. J. Apl. Teknol. Pangan 6 (2): 2. [Indonesia]

Earl, Dent A, vonHoldt, M. Bridgett. 2012. Structure Harvester: A website and program for visualizing structure output and implementing Evanno method. Conserv. Genet. Resour 4 (2): 359-361. DOI: 10.1007/s12686-011-9548-7

Effendy, Respatijarti, Waluyo B. 2018. Genetic variability and heritability characters of yield component and yield of physalis (Physalis sp.). J Agro 5 (1): 30-38. DOI: $10.15575 / 1864$

Ekowati G, Yanuwiadi B, Azrianingsih R. 2015. A source of glucomannan from edible Araceae in East Java. J-PAL 6 (1): 32-41. [Indonesian]

Ezeabara CA, Okeke C, Amadi J. 2015. Phytochemical, proximate, mineral and vitamin investigations of cormels of five varieties of Colocasia esculenta (L.) Schott found in Anambra State, Southeastern Nigeria. Am J Life Sci Resour 3 (4): 273-281.

Eze CE, Nwofia GE. 2016. Variability and inter-relationships between yield and associated traits in taro (Colocasia esculenta (L.) Schott). J Exp Agric Intl 14 (2): 1-13. DOI: 10.9734/JEAI/2016/27053.

Hang DT, Vanhanen L, Savage G. 2013. Effect of simple processing methods on oxalate content of taro petioles and leaves grown in central Viet Nam. Food Sci Technol 50: 259-263.

Hapsari RT. 2014. Estimation of genetic diversity and correlations between yield components of early maturing green beans. Bull Plasma Nutfah 20 (2): 51-58. [Indonesian] 
IPGRI. 1999. Descriptor for Taro (Colocasia esculenta). International Plant Genetic Resources Institute, Rome

ITPC. 2014. Market Brief Satoimo (Taro). ITPC, Osaka.

Jalata Z, Ayana A, Zeleke H. 2011. Variability, heritability and genetic advance for some yield and yield-related traits in Ethiopian barley (Hordeum vulgare L.) landraces and crosses. Intl J Plant Breeding Genet 5 (1): 44-52. DOI: 10.3923/ijpbg.2011.44.52

Kallo R, Satna A, Nappu MB. 2019. Prospects for the development of Japanese satoimo taro in South Sulawesi. Bull Diseminasi Teknol Pertanian 1 (1): 1-5. [Indonesian]

Kaushal P, Kumar V, Sharma HK. 2012. Comparative study of physicochemical, functional, antinutritional and pasting properties of taro (Colocasia esculenta), rice (Oryza sativa) flour, pigeon pea (Cajanus cajan) flour and their blends. Food Sci Technol 48: 59-68

Laosa A, Darman S, Alam MN. 2016. Analysis of production and income of Japanese taro farming system in Tinangkung Village South Tinangkung Sub District of Banggai Kepulauan District. J Agrol 23 (3): 174-181. [Indonesian]

Mergedus A, Kristl J, Ivancic A, Sober A, Sustar V, Krizan T, Lebot V. 2015. Variation of mineral composition in different parts of taro (Colocasia esculenta) corms. Food Chem 170: 37-46. DOI: 10.1016/j.foodchem.2014.08.025.

Meydina A, Barmawi M, Sa'diyah N. 2015. Genetic variability and heritability of agronomy characters of soybean (Glycine max [L.] Merrill) F5 generation as the results of crosses WILIS X B3570. J Penelitian Pertanian Terapan 15 (3): 200-207

Mulualem T, Michael G. 2013. Study on genotypic variability estimates and interrelationship of agronomic traits for selection of taro (Colocasia esculenta (L.) Schott) in Ethiopia. Sky J Agric Resour 2 (11): 154-158.

Naik VV, Patil N, Aparadh VT, Karadge BA. 2014. Methodology in determination of oxalic acid in plant tissue: A comparative approach. J Global Trends Pharm Sci 5 (2): 1662-1672.

Njintang NY, Boudjeko T, Tatsadjieu LN, Nguema-ona E, Scher J, Mbofung CMF. 2011. Compositional, spectroscopic and rheological analyses of mucilage isolated from taro (Colocasia esculenta L. Schott) corms. J Food Sci Technol. DOI: 10.1007/s13197-011-05800 .

Nurilmala F, Mardiana D. 2019. Nutrients and anti-nutrients content analysis of Bogor taro mutant clone (Colocasia esculenta). IOP Conf. Series: Earth Environ Sci 334: 012070. DOI: 10.1088/17551315/334/1/012070

Pitoyo A, Prameta AA, Marsusi, Suratman, Suranto. 2018. Morphological, anatomical and isozyme variability among taro (Colocasia esculenta) accessions from southeastern part of Central Java, Indonesia. Biodiversitas 19 (5): 1811-1819. DOI: 10.13057/biodiv/d190531.

Plucknett DL. 1983. Taxonomy of the genus colocasia. In: Wang JK (eds) A Review of Colocasia esculenta and its potentials. Univ Hawaii, Honolulu, USA.

Prana MS. 2007. Study on flowering biology of taro (Colocasia esculenta (L.) Schott.). Biodiversitas 8 (1): 63-66.

Poerwanto R, Sulaeman A, Wattimena GA. 2012. The history and development of the green revolution, the biotechnology revolution and the sustainable green revolution. In: Poerwanto R, Siregar IZ, Suryani A (eds) Merevolusi Revolusi Hijau. IPB Press, Bogor. [Indonesian]

Rashmi DR, Raghu N, Gopenath TS, Palanisamy P, Bakthavatchalam P, Karthikeyan M, Gnanasekaran A, Ranjith MS, Chandrashekrappa GK, Basalingappa KM. 2018. Taro (Colocasia esculenta): An overview. J Med Plants Stud 6 (4): 156-161.

Rosdanelly CNR, Agussabti, Azhar. 2018. The prospect of Japanese taro cultivation (Colocasia esculenta var antiquorum) at Agricultural
Training Centre Saree, Aceh Besar. J Pertanian Unsyiah 3 (1): 380390. http://www.jim.unsyiah.ac.id/JFP. [Indonesian]

Rudyatmi E, Rahayu ES. 2014. Characterization of Middle Java local taro (Germplasm identification as part of conservation effort). Sainteknol 12 (1): 1-8 [Indonesian]

Santosa E, Mine Y, Nakata M, Lian C, Sugiyama N. 2010. Genetic diversity of cultivated elephant foot yam (Amorphophallus paeoniifolius) in Kuningan, West Java as revealed by microsatellite markers. J Appl Hortic 12 (2): 125-128.

Santosa E, Lian CL, Sugiyama N, Misra RS, Boonkorkaew P, Thanomchit K. 2017. Population structure of elephant foot yams (Amorphophallus paeoniifolius (Dennst.) Nicolson) in Asia. PLoS ONE 12: 6. DOI: 10.1371/journal.pone.0180000.

Shah RB, Li B, Wang L, Liu S, Li Y, Wei X, Weiping J, Zhenshun L. 2015. Health benefits of konjac glucomannan with special focus on diabetes. Bioact Carbohyd Diet Fibre 5 (2): 179-187. DOI: 10.1016/j.bcdf.2015.03.007.

Sinaga KA, Murningsih, Jumari. 2017. Identification of edible Araceae in Semarang, Middle Java. Bioma 19 (1): 18-21. [Indonesian]

Sleper DA, Poehlman JM (eds.). 2006. Breeding Field Crop. 5 $5^{\text {th }}$ ed. Blackwell Publishing, Oxford.

Stansfield WD. 1983. Theory and Problems of Genetic. $2^{\text {nd }}$ ed. McGrawHill, New York.

Susepah I. 2018. Profile and performance of mindring enterprise in the informal sector, especially the Kuningan migrants in Padukuhan Pandean VII Sidoluhur, Godean, Sleman, Yogyakarta. Jurnal $\begin{array}{llll}\text { Pemberdayaan } & \text { Masyarakat } 2 \text { (1): } 87-108 . & \text { DOI: }\end{array}$ 10.14421/jpm.2018.021-05. [Indonesian]

Syukur M, Sujiprihati S, Yunianti R. 2015. Technic of Plant Breeding. $2^{\text {nd }}$ ed. Penebar Swadaya, Jakarta. [Indonesian]

Taufiq FM. 2015. Japanese Taro, Export Value Food Commodity. https://www.kompasiana.com/masfathan66. [Indonesian]

Temesgen M, Retta N. 2015. Nutritional potential, health and food security benefits of taro Colocasia esculenta (L.): A Review. Food Sci Qual Manag 36: 23-30.

Tester RF, Al-Ghazzewi FH. 2016. Beneficial health characteristics of native and hydrolysed konjac (Amorphophallus konjac) glucomannan. J Sci Food Agric 96: 3283-3291. DOI: 10.1002/jsfa.7571.

Vandenbroucke H, Mournet P, Vignes H, Chaïr H, Malapa R, Duval MF, Lebot V. 2016. Somaclonal variants of taro (Colocasia esculenta Schott) and yam (Dioscorea alata L.) are incorporated into farmer's varietal portfolios in Vanuatu. Genet Resour Crop Evol 63: 495-511.

Widjanarko SB, Megawati J. 2015. Comparation between colorimetric and gravimetric methods of glucomannan analysis to konjac. J Pangan Agroindustri 3 (4): 1584-1588. [Indonesian]

Yang D, Yuan Y, Wang L, Wang X, Mu R, Pang J, Xiao J, Zheng Y. 2017. A review on konjac glucomannan gels: Microstructure and application. Intl J Mol Sci 18 (11): 2250. DOI: 10.3390/ijms 18112250 .

Yu JG, Liu P, Duan JA, Tang ZX, Yang Y. 2015. Itches-stimulating compounds from Colocasia esculenta (taro): Bioactive-guided screening and LC-MS/MS identification. Bioorg Med Chem Lett 25: 4382-4386

Yunus A, Salman D, Demmallino EB, Viantika NM. 2016. Sociotechnical change and institutional adjustment in paddy rice farming during post green revolution in Indonesia. Intl J Agric Syst 4 (2): 218-227.

Zalewski BM, Chmielewska A, Szajewska H. 2015. The effect of glucomannan on body weight in overweight or obese children and adults: A systematic review of randomized controlled trials. Nutr 31: 437-444. 